\title{
A Case of Hemangioma in the External Auditory Canal with Pulsatile Tinnitus
}

\author{
Hyeonseok Kim ${ }^{1}$, Jinwon Seo ${ }^{2}$, and Hyo-Jeong Lee ${ }^{1}$ \\ ${ }^{1}$ Departments of Otorhinolaryngology-Head and Neck Surgery, ${ }^{2}$ Pathology, Hallym University College of Medicine, Chuncheon, Korea
}

\section{박동성 이명으로 발현된 외이도 혈관종 1 예}

김현석 ${ }^{1} \cdot$ 서진원 $^{2} \cdot$ 이효정 ${ }^{1}$

한림대학교 의과대학 이비인후-두경부외과학교실, ${ }^{1}$ 병리학교실 ${ }^{2}$

\author{
Received June 12, 2016 \\ Revised September 23, 2016 \\ Accepted October 17, 2016 \\ Address for correspondence \\ Hyo-Jeong Lee, MD \\ Department of Otorhinolaryngology- \\ Head and Neck Surgery, \\ Hallym University \\ College of Medicine, \\ 22 Gwanpyeong-ro 170beon-gil, \\ Dongan-gu, Anyang 14068, Korea \\ Tel +82-31-380-3849 \\ Fax $+82-31-386-3860$ \\ E-mail hyojlee@hallym.ac.kr
}

Hemangiomas are relatively common in the head and neck region, but their occurrence in the temporal bone are extremely rare. The hemangioma of the external auditory canal (EAC) is a rare otologic entity as only 22 cases of hemangioma of the EAC have been reported worldwide. Here we report a patient presenting with pulsatile tinnitus, which turned out to be caused by capillary hemangioma arising from the posterior medial portion of external auditory canal touching the tympanic membrane. Surgical excision of the tumor was successful. The clinical manifestations and management of benign vascular lesions of the EAC are discussed with a review of literature. Korean J Otorhinolaryngol-Head Neck Surg 2017;60(3):140-3

Key Words External auditory canal $\cdot$ Hemangioma $\cdot$ Tinnitus.

\section{서 론}

체성 이명의 원인은 다양하며 혈관 잡음, 근수축, 혹은 이 관개방 등이 원인으로 알려져 있다. 이 중 환자가 심장박동과 일치하는 박동성 이명을 호소할 때는 혈관 잡음에 의한 경우 가 많으며 영상학적 검사 및 신체검사를 시행하여 그 원인을 찾아야 한다. ${ }^{1)}$ 혈관종은 선천성 두경부 양성종양의 가장 흔 한 원인이며 병리조직학적으로 해면상, 모세상 및 혼합형으 로 분류된다. ${ }^{2)}$ 피부로 둘러싸인 신체 어느 곳에서나 생길 수 있지만 고막을 포함한 외이도에서의 발생은 극히 드물게 보 고되고 있으며, ${ }^{3-7)}$ 특히 외이도에서 발생한 혈관종은 전 세계 적으로 22예, 그중 모세혈관종은 2예 ${ }^{6,7)}$ 만이 보고되어 있다. 아직 발생 기전은 정확하게 밝혀지지 않았으며 소아의 경우 와는 달리 성인에서는 자연 퇴행이 잘 이루어지지 않아 이에 대한 치료가 필요하다.

저자들은 박동성의 이명을 주소로 내원한 환자에서 좌측
외이도에 발생한 모세상혈관종 1 예를 후이개 접근법으로 일 괴성으로 제거하여 좋은 결과를 경험하였기에 문헌고찰과 함께 보고하는 바이다.

\section{증 려}

45세 남자 환자가 4개월 전부터 하루 종일 심장박동과 같 이 뛰는 듯하게 지속되는 좌측의 박동성 이명을 주소로 내 원하였다. 환자는 좌측 박동성 이명 이외의 청력저하, 이통, 이루, 현훈, 안면마비 등의 소견은 보이지 않았다. 특별한 기저 질환은 없었으며 가족력 및 과거력상에서도 특이병력은 없었 다. 외이도와 고막의 이경검사에서 좌측 외이도 후상방에 표 면이 매끄럽고 경계가 명확한 적색의 종물이 관찰되었고 고 막은 종물로 인해 반 정도 가려져 있었다(Fig. 1A).

내원 당일 시행한 순음청력검사(4분법)상 좌측 기도 청력 은 $5 \mathrm{~dB}$, 어음명료도는 $100 \%$ 로 정상 청력을 보였고(Fig. 2A) 

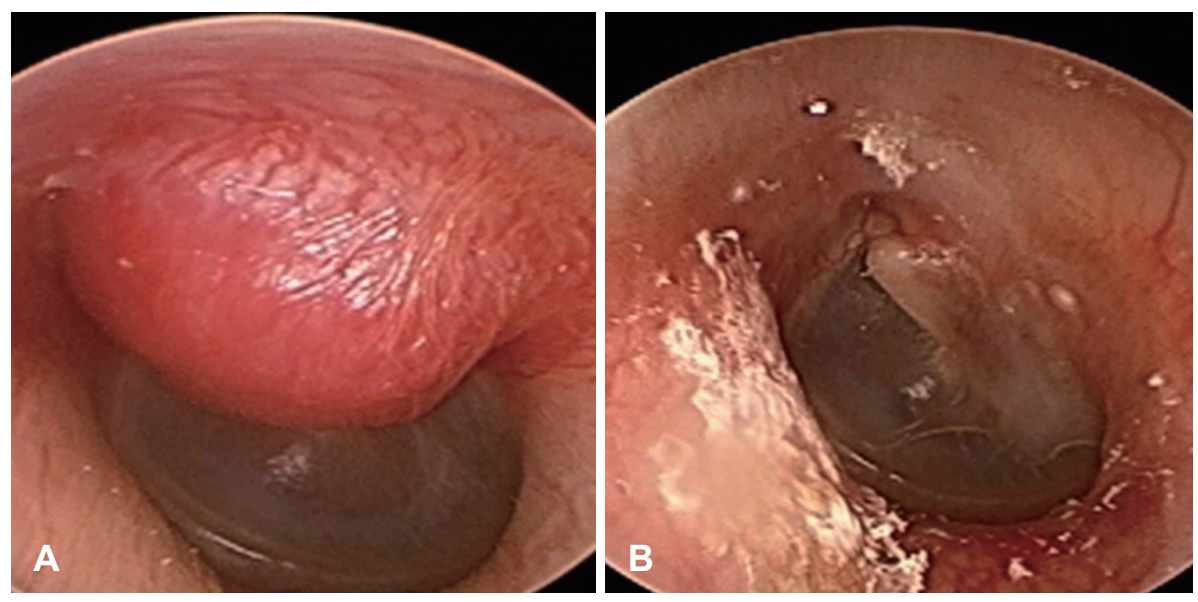

Fig. 1. The photographs of preoperative (A) and postoperative (B) otoscopic findings. Preoperative otoscopic finding of the left ear shows a pinkish to reddish colored mass in the external auditory canal (EAC) (A). Postoperative otoscopic finding of ear shows a normal tympanic membrane and $\mathrm{EAC}(\mathrm{B})$.
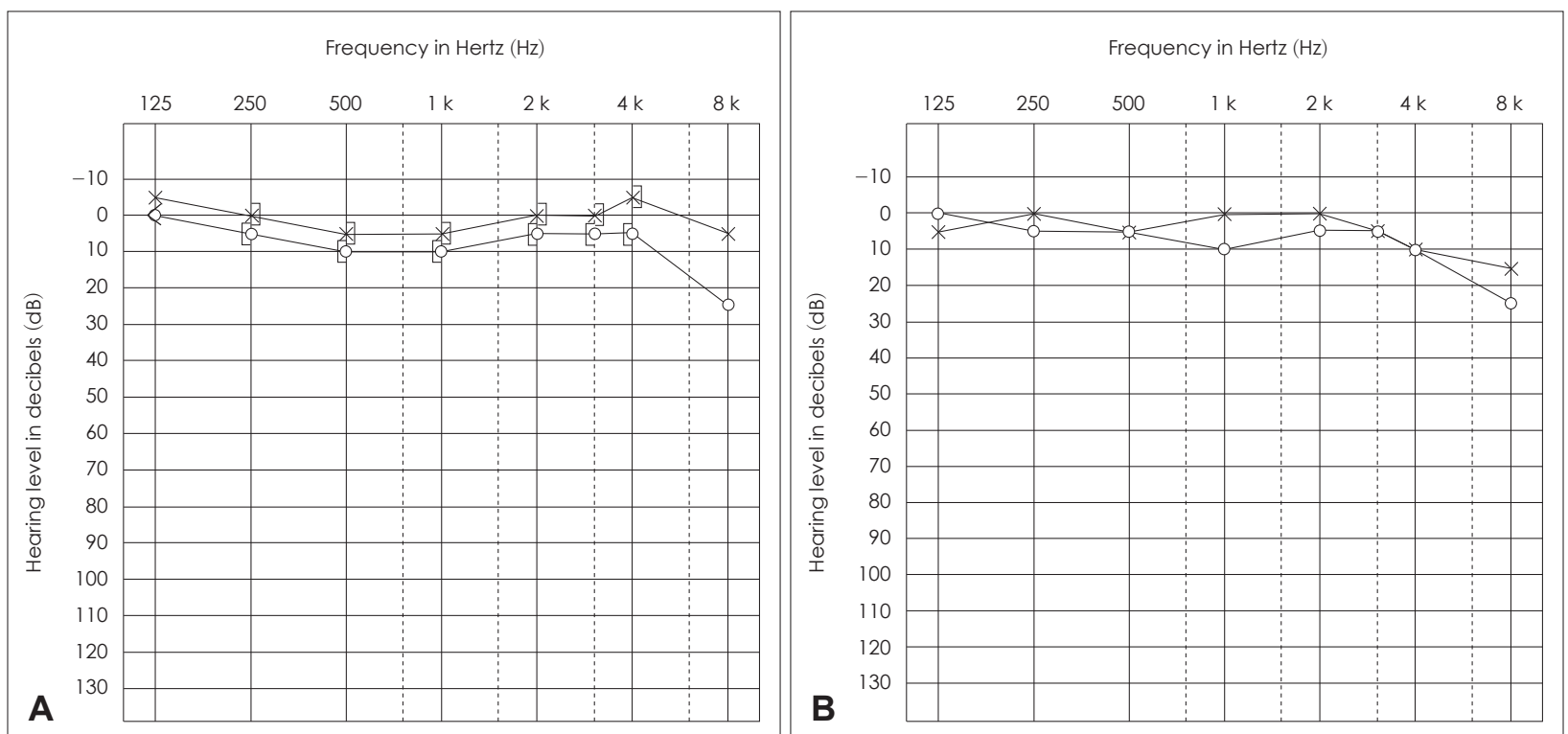

Fig. 2. Pure tone audiogram shows left-sided normal hearing level before operation (A), post operation (B).

이명검사에서는 "샥샥" 하는 초침소리와 같은 기계음이 들린 다고 했으며 순음, 백색 잡음, 어음 잡음을 들려주었으나 비 슷한 소리는 없다고 하였다. 종물을 감별하기 위해 측두골 전산화단층촬영 및 자기공명영상촬영을 시행하였다.

측두골 전산화단층촬영에서 좌측 외이도에 경계가 비교적 분명한 연부조직 음영의 종물이 고막과 접하여 관찰되었으나 중이나 골성 외이도로의 침범은 없었다(Fig. 3). 자기공명영상 에서는 $\mathrm{T} 1$ 강조영상에서 종물이 혈관과 비슷한 정도의 조영증 강을 보이고 있어 혈관종과 같은 혈관분포가 높은 종물로 판 독되었다.

좌측의 박동성 이명을 호소한다는 점과, 외이도와 고막의 이학적 소견 및 영상진단검사를 바탕으로 외이도 혈관종으 로 진단하고 전신마취로 후이개 접근법을 통하여 외이도 피 부를 골성 외이도로부터 박리하였다. 외이도 후상방에 존재
하는 종물의 안전역을 확보하기 위해 주변 정상 피부를 일부 포함하여 일괴성으로 제거하였다. 종물을 제거한 후 관찰한 골성 외이도에는 특이소견이 없었으며 수술 중 출혈은 거의 없었다. 외이도 피부결손 부위는 $3 \mathrm{~mm}$ 내외였다. 수술 중 종 물과 접하고 있어 종물과 함께 제거된 고막 후상방의 일부 결손을 재건하기 위해 측두근막을 이용하여 고막재건술을 시행하고 Gelfoam ${ }^{\circledR}$ (Pfizer Inc., New York, NY, USA) 패킹 후에 수술 부위를 봉합하였다. 고막재건을 위해 삽입된 측두 근막이 외이도 피부결손부에 함께 덮이도록 하였다.

제거한 종물의 크기는 $0.8 \times 0.6 \times 0.4 \mathrm{~cm}$ 크기로 병리조직 학으로 모세혈관들의 소엽성 증식이 관찰되어 모세상혈관종 으로 진단되었다(Fig. 4).

환자는 수술 직후부터 박동성 이명이 소멸되었으며, 특이한 합병증 없이 수술 후 2 일째에 퇴원하였다. 수술 후 3 개월 뒤 
Fig. 3. Preoperative temporal bone axial (A) and enhanced (B) CT scans demonstrate a soft tissue lesion in the external auditory canal.
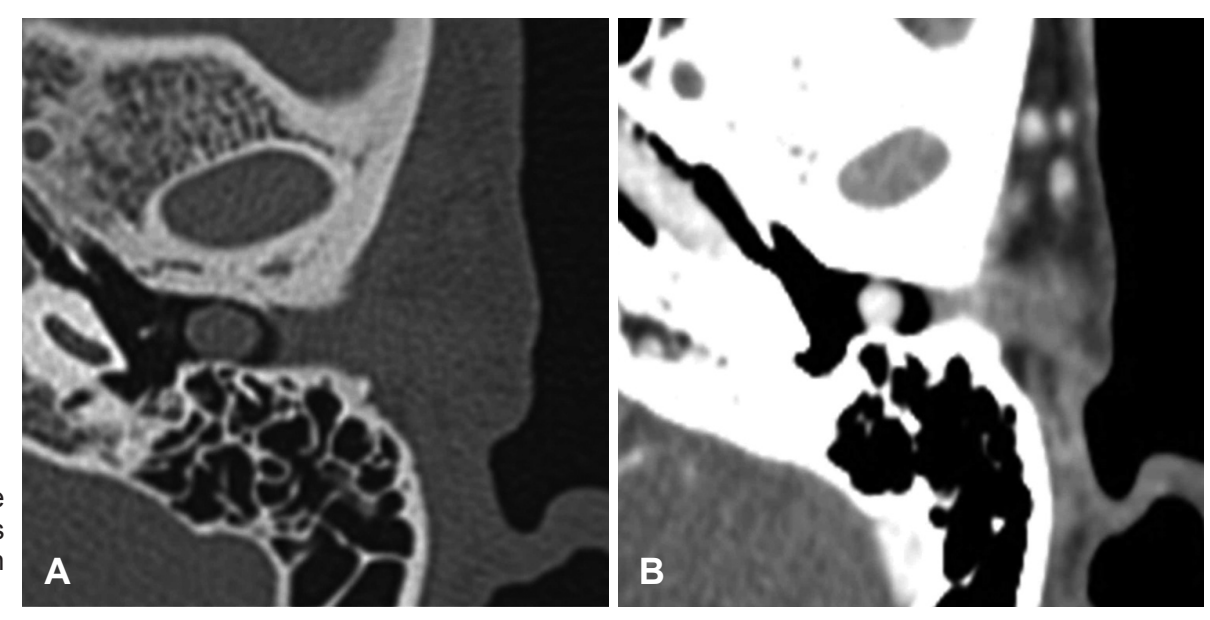

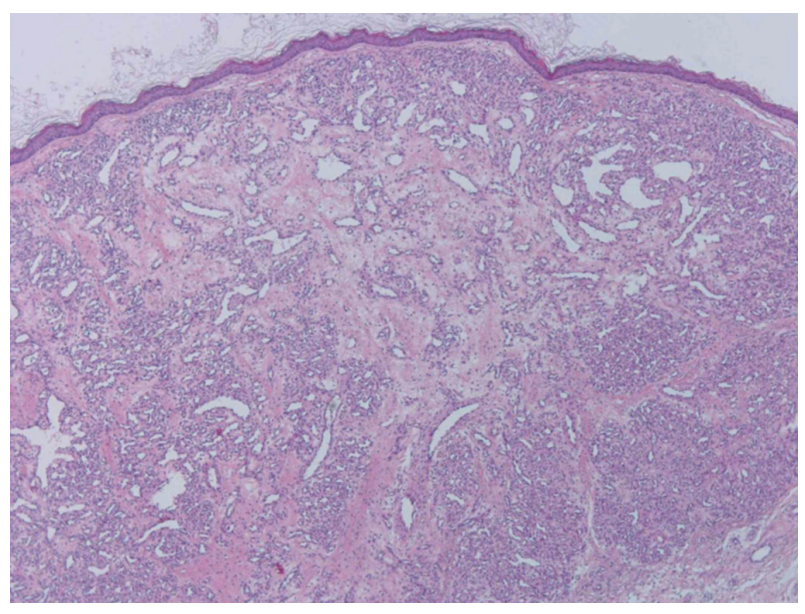

Fig. 4. The photograph of histopathologic finding. Microscopically, the tumor shows lobular proliferation of small capillaries (H\&E stain, $\times 100)$.

시행한 이내시경검사에서 정상적인 외이도와 고막 소견을 보이 고 있었으며(Fig. 1B), 순음청력검사상에서도 기도 $2 \mathrm{~dB}$, 어음 명료도는 $100 \%$ 로 정상 청력을 유지하고 있었다(Fig. 2B). 현 재 환자는 수술을 시행 받은 지 1년째로 외이도 및 고막에 재 발된 소견 없이 정기적인 외래 관찰 중에 있다.

\section{고 찰}

양성종양인 혈관종은 선천성 두경부 종양의 가장 흔한 원 인으로 출생 때부터 생후 1 세까지 약 $85 \%$ 가 발생되고 2 세 이 후에는 서서히 퇴화하여 대부분 12 세까지 자연관해가 되며 성인에서는 자연관해가 드물다. ${ }^{2}$ 조직학적으로 한 개의 내피 세포층으로 둘러싸여 있는 정상 또는 비정상적인 형태의 혈 관의 증식으로 구성이 되어 있다. 발생기전과 원인은 아직 명확 히 규명되지는 않았지만, 혈관종을 가진 소아의 혈액과 소변에 서 angiogenic peptide basic fibroblast growth factor(bFGF)
수치가 상승되어 있어 $\mathrm{bFGF}$ 가 혈관종의 발생에 관계가 있다 고 추정된다. ${ }^{8}$

혈관종의 위치가 고막을 포함한 외이도 또는 외이도로 보고 된 바로는 1972년 Freedman 등'에 의해 처음으로 보고되었 으며 외이도의 혈관종을 조직학적으로 나누어 보았을 때 모 세상혈관종은 1988년 Krueger와 Porto에 에 의해 보고되었으 며 국내에서는 $1^{1}$ 예 ${ }^{7)}$ 가 보고되었을 정도로 드물게 나타난다

(Table 1).

증상은 환측의 청력감소, 이명, 이충만감, 이루, 이통 등으 로 다양하게 나타났으며 특별한 증상 없이 발견되는 경우도 있었다. 종물은 주로 외이도 후상벽에 발생했다고 보고되었 으며 ${ }^{6)}$ 혈관종의 위치가 고막을 포함한 외이도 또는 외이도인 경우만을 분류하여 문헌을 고찰해 보았을 때 주로 청력저하, 청력저하와 동반된 이명을 호소하고 있었으며, 정상적인 청력 을 가지면서 박동성의 이명을 주소로 내원하여 외이도 혈관 종으로 진단을 받은 경우는 본 증례가 처음이다. 이에 대한 임상적인 의미가 있다고 생각되며, 본 증례의 경우에서는 외 이도에 발생한 혈관종의 크기가 커짐에 따라 고막의 후상방 에 종물의 외연이 접하게 되어 박동성의 이명이 나타났다고 생각된다.

이학적 검사에서는 이내시경상 특징적으로 표면이 매끄럽 고 모양이 둥근 적색의 종물로 관찰되므로 쉽게 진단이 가능 하다. ${ }^{6,8,10)}$ 혈관종의 병변 범위의 확인에 있어서는 측두골 전 산화단층촬영이 가장 좋은 영상진단검사 ${ }^{11)}$ 이며, 외이도에 비 정상적인 연부조직 음영이 특징적인 소견이다. 본 증례에서도 측두골 전산화단층촬영에서 좌측 외이도에 경계가 비교적 분명한 연부조직 음영의 종물이 보였으며 골성 외이도나 중이 로의 침범은 없는 것을 수술 전에 확인할 수 있었으며 추가적 으로 시행한 자기공명영상에서도 좌측 외이도에 $\mathrm{T} 1$ 강조영상 에서 종물이 혈관과 비슷한 정도의 조영증강을 보이고 있어 
Table 1. Reported cases of hemangioma of the external auditory canal

\begin{tabular}{|c|c|c|c|c|c|c|}
\hline Author (year) & Age & Sex & Location & Otologic symptom & Surgical approach & Pathology \\
\hline Freedman, et al. (1972) & 52 & $M$ & $\mathrm{EAC}+\mathrm{TM}$ & None & Excision+myringoplasty & Cavernous \\
\hline Freedman, et al. $(1972)^{9)}$ & 57 & M & $\mathrm{EAC}+\mathrm{TM}$ & None & Excision+myringoplasty & Cavernous \\
\hline Kemink, et al. $(1983)^{3)}$ & 52 & M & $\mathrm{EAC}+\mathrm{TM}$ & None & Excision +mastoidectomy & Cavernous \\
\hline Hawke and van Nostrand $(1987)^{4)}$ & 55 & M & EAC & Otorrhea & Excision & Cavernous \\
\hline Krueger and Porto $(1988)^{5)}$ & 50 & M & EAC & $\mathrm{HL}$ & Excision & Capillary \\
\hline Jackson, et al. $(1990)^{6}$ & 60 & $\mathrm{~F}$ & $\mathrm{EAC}+\mathrm{TM}$ & $\mathrm{HL}$ & Excision & Mixed \\
\hline Joshi and Wakode (1999) ${ }^{12)}$ & 16 & M & $\mathrm{EAC}+\mathrm{TM}$ & Otorrhea & Excision + mastoidectomy & Cavernous \\
\hline Cho, et al. $(2001)^{7)}$ & 44 & M & $\mathrm{EAC}+\mathrm{TM}$ & $\mathrm{HL}$ & Excision+myringoplasty & Capillary \\
\hline Reeck, et al. $(2002)^{8)}$ & 53 & M & EAC & $\mathrm{HL}+\mathrm{T}$ & Excision & Cavernous \\
\hline Limb, et al. $(2002)^{10)}$ & 67 & $\mathrm{~F}$ & EAC & $\mathrm{HL}+\mathrm{T}$ & Excision & Cavernous \\
\hline Song, et al. $(2006)^{13)}$ & 46 & M & EAC & $\mathrm{HL}+\mathrm{T}$ & Excision & Cavernous \\
\hline Magliulo, et al. $(2007)^{14)}$ & 63 & M & $\mathrm{EAC}+\mathrm{TM}$ & $\mathrm{HL}+\mathrm{T}$ & Excision +mastoidectomy & Cavernous \\
\hline Martines, et al. $(2012)^{15)}$ & 59 & M & EAC & $\mathrm{HL}+\mathrm{T}$ & Excision & Cavernous \\
\hline Kim, et al. (this case) & 45 & M & EAC & T & Excision+myringoplasty & Capillary \\
\hline
\end{tabular}

EAC: external auditory canal, $\mathrm{HL}$ : hearing loss, $\mathrm{T}$ : tinnitus

혈관종과 같이 혈관분화가 높은 종물로 판독할 수 있었다.

두경부 영역에서 일반적인 혈관종의 치료로는 절제술, 스테 로이드 주사, 소작술, 경화치료, 레이저치료 등으로 다양하나 4,9$)$ 외이도에 발생한 경우에는 절제술이 가장 효과적인 치료이 다. 수술 전 색전술은 일반적으로 필요하지 않으며 이내 접근 법이 병변의 노출 및 완전 절제를 위해 선호되는 술식이다. ${ }^{377}$ 본 증례에서는 출혈로 인한 시야장애의 가능성을 고려하여 후이개 접근법을 통해 병변을 완전 절제하였다.

재발과 관련해서는 1990년 Jackson 등6)이 외이도의 혼합 형 혈관종에서 단순 절제술을 시행한 후 재발하여 부분적인 측두골 절제술까지 시행하여 좀 더 광범위한 절제의 필요성을 제기하였으나 현재까지 외이도 혈관종이 자연적 경과나 수술 후에 악성으로 전환된다는 보고는 없다.

아직 발표된 증례수가 많지 않지만 본 증례 및 현재까지 보 고된 증례를 보았을 때 외이도에 발생한 혈관종의 치료는 충 분한 절제연을 확보한 완전 절제술이 가장 효과적인 치료방 법이 될 것으로 생각된다.

\section{Acknowledgments}

This work was supported by the National Research Foundation of Korea (NRF) grant funded by the Korean Government (NRF2016R1A2B4016330).

\section{REFERENCES}

1) Otto KJ, Hudgins PA, Abdelkafy W, Mattox DE. Sigmoid sinus diverticulum: a new surgical approach to the correction of pulsatile tinnitus. Otol Neurotol 2007;28(1):48-53.
2) Albritton F, Lenis A. Cavernous hemangioma of the tympanic membrane. Ear Nose Throat J 1994;73(11):808.

3) Kemink JL, Graham MD, McClatchey KD. Hemangioma of the external auditory canal. Am J Otol 1983;5(2):125-6.

4) Hawke M, van Nostrand P. Cavernous hemangioma of the external ear canal. J Otolaryngol 1987;16(1):40-2.

5) Krueger RA, Porto D. Pathologic quiz case 2. Benign capillary hemangioma. Arch Otolaryngol Head Neck Surg 1988;114(12): $1480-1,1483$

6) Jackson CG, Levine SC, McKennan KX. Recurrent hemangioma of the external auditory canal. Am J Otol 1990;11(2):117-8.

7) Cho KH, Kim KH, Lee KS, Yang HS. A case of capillary hemangiomain the external auditory canal. Korean J Otolaryngol-Head NeckSurg 2001;44(9):993-6.

8) Reeck JB, Yen TL, Szmit A, Cheung SW. Cavernous hemangioma of the external ear canal. Laryngoscope 2002;112(10):1750-2.

9) Freedman SI, Barton S, Goodhill V. Cavernous angiomas of the tympanic membrane. Arch Otolaryngol 1972;96(2):158-60.

10) Limb CJ, Mabrie DC, Carey JP, Minor LB. Hemangioma of the external auditory canal. Otolaryngol Head Neck Surg 2002;126(1):74-5.

11) Chakeres DW, Kapila A, LaMasters D. Soft-tissue abnormalities of the external auditory canal: subject review of CT findings. Radiology 1985;156:105-9.

12) Joshi SV, Wakode PT. A rare case of haemangioma of the tympanic membrane and external auditory canal. Indian J Otolaryngol Head Neck Surg 2000;52(2):171.

13) Song SY, Choi YH, Bai CH. Cavernous hemangioma of the external auditory canal: a case report. Korean J Otolaryngol-Head Neck Surg 2006;49(8):845-8.

14) Magliulo G, Parrotto D, Sardella B, Della Rocca C, Re M. Cavernous hemangioma of the tympanic membrane and external ear canal. Am J Otolaryngol 2007;28(3):180-3.

15) Martines F, Bentivegna D, Maira E, Marasà S, Ferrara S. Cavernous haemangioma of the external auditory canal: clinical case and review of the literature. Acta Otorhinolaryngol Ital 2012;32(1):54-7. 